\title{
PENINGKATAN PEMAHAMAN PENEGAKAN HAK ASASI MANUSIA MELALUI PEMANFAATAN MEDIA PEMBELAJARAN BERBASIS TIK PADA SISWA KELAS XI SMA NEGERI COLOMADU KABUPATEN KARANGANYAR TAHUN 2016
}

\author{
Jacksone Christiawan Puka Puka \\ Email : jacksonechristiawanpukapuka@yahoo.co.id
}

\begin{abstract}
The aims achieved in this research is to know the influence of computer information technology based learning media to support learning toward learning achievement for the students of grade XI SMA N Colomadu in academic year 2015/2016. This research is a qualitative research. In this research, the population was the students of grade XI SMA N Colomadu with the total number 319 students. The sample was taken using Quota random technique with the sample 15-20\% from the population. The result of counting was 67 students. Technique in collecting data in this research was test method. Test method was used to collect data about the influence of computer information technology based learning media. Technique analyzing data used in this research was descriptive critical comparative. This research was conducted in one cycle consisted of planning, implementation, observation, and reflection. Based on the research and discussion, it was found that the use of computer information technology based learning media to improve material comprehension about enforcement of human right in Indonesia for the students of grade XI SMA Negeri Colomadu Karanganyar in the year of 2016, in the beginning it was shown that from 33 students, which was not passed the minimum score standart or under 70,33 students got 63,33. In cycle 1, students who passed the minimum score standard or got the score more than 70 was 7 students $(21.21 \%)$ meanwhile the students who was not passed the minimum score standard was students $(78.79 \%)$ with the mean score 56.06. in cycle II, student who passed the minimum score was 32 students (100\%) with the mean score 83.12. based on the discussion above, the researcher can conclude that the use of computer information technology based learning media can develop material understanding about the enforcemet of human right in Indonesia for the students of grade XI SMA Negeri Colomadu Karanganyar in the academic year 2016/2017.
\end{abstract}

\begin{abstract}
Abstrak: Tujuan yang dicapai dalam penelitian ini adalah Mengetahui pengaruh media pembelajaran berbasis TIK dalam menunjang pembelajaran terhadap prestasi belajar pada siswa kelas XI SMA N Colamdu Tahun Pelajaran 2015/2016. Penelitian ini merupakan penelitian kualitatif. Dalam penelitian ini, populasinya adalah siswa kelas XI SMA Negeri Colomadu yang berjumlah 319 siswa. Sampel diambil dengan teknik random dengan cara Quota random sampling dengan mengambil sampel sebanyak 15-20\% dari populasi, dengan hasil perhitungan yang berjumlah 67 siswa. Teknik pengumpulan data dalam penelitian ini menggunakan Metode tes. Metode tes digunakan untuk mengumpulkan data mengenai pengaruh media pembelajaran berbasis TIK dengan prestasi belajar. Triangulasi yang digunakan dalam penelitian ini adalah pertama triangulasi sumber dengan membandingkan apa yang dikatakan siswa dan guru. Triangulasi metode yaitu pembuktian dengan observasi mengenai pelaksanaan penerapan media pembelajaran berbasis TIK. Teknik analisis data menggunakan deskriptif kritis komparatif. Pelaksanaan ini dilakukan dalam satu siklus yang terdiri dari perencanaan, pelaksanaan, observasi, dan refleksi. Berdasarkan penelitian dan pembahasan maka diperoleh kesimpulan bahwa penggunaan media pembelajaran berbasis TIK dapat meningkatkan pemahaman materi tentang penegakan hak asasi manusia di Indonesia siswa kelas XI SMA Negeri Colomadu Karanganyar tahun ajaran 2016, pada kondisi awal menunjukan bahwa dari 33 siswa, yang dinyatakan tidak tuntas atau mempunyai nilai dibawah 70 yaitu sebanyak 33 siswa (100\%) dengan rata-rata nilai 63,03. Pada siklus I siswa yang dinyatakan tuntas atau mempunyai nilai diatas 70 sebanyak 7 siswa $(21,21 \%)$ sedangkan siswa yang belum tuntas dinyatakan 26 siswa $(78,79 \%)$ dengan rata-rata 56,06. Pada siklus II siswa tuntas sebanyak 32 siswa (100\%) dengan rata-rata 83,12. Dengan demikian dapat peneliti menyimpulkan bahwa penggunaan media pembelajaran berbasis TIK dapat meningkatkan pemahaman materi tentang penegakan hak asasi manusia di Indonesia pada siswa kelas XI SMA Negeri Colomadu Karanganyar tahun ajaran 2016/2017.
\end{abstract}

Kata Kunci : Media Pembelajaran Berbasis TIK, Prestasi Belajar 


\section{A. PENDAHULUAN}

Dewasa ini teknologi informasi dan komunikasi sangat erat pengaruhnya dengan kehidupan manusia tidak terkecuali di dunia pendidikan. Memasuki abad teknologi informasi dan komunikasi (TIK) sekarang ini sangat dirasakan kebutuhan dan pentingnya penggunaan ICT atau information and communications technology dalam kegiatan pembelajaran. Melalui pemanfaatan TIK kita dapat meningkatkan mutu pendidikan, yaitu dengan cara membuka lebar-lebar terhadap akses ilmu pengetahuan dan penyelenggaraan pendidikan bermutu, terutama dengan menggunakan penerapan high tech dan high touch approach. Sistem teknologi informasi dan komunikasi memberikan jangkauan yang lebih luas, cepat, efektif, dan efisien terhadap penyebarluasan informasi ke berbagai penjuru dunia. Teknologi informasi berkembang sejalan dengan perkembangan teori dan komunikasi dan teknologi yang menunjang terhadap praktik kegiatan pembelajaran. Pembelajaran berbasis komputer (PBK), pembelajaran berbasis web atau e-learning, pembelajaran berbantukan komputer (CAI), pembelajaran berbasis audio-visual (AVA), pembelajaran berbasis multimedia adalah salah satu bentuk pemanfaatan TIK yang perlu dilaksanakan dalam dunia pendidikan dewasa ini. Kegiatan pembelajaran merupakan kegiatan yang paling pokok dalam keseluruhan proses pendidikan. Hal ini berarti bahwa pencapaian tujuan pendidikan banyak bergantung kepada bagaimana proses pembelajaran dirancang dan dijalankan secara profesional. Setiap kegiatan pembelajaran selalu melibatkan dua pelaku aktif, yaitu guru dan siswa. 1 adalah pencipta kondisi belajar siswa yauy didesain secara sengaja, sistematis. Dan berkesinambungan. Sedangkan siswa sebagai peserta didik merupakan pihak yangB menikmati kondisi belajar yang diciptakan guru tersebut. Diharapkan dengan adaya perkembangan teknologi informasi dan komunikasi yang telah menjadi kebutuhan dalam kehidupan manusia dapat digunakan secara baik dalam kegiatan belajar mengajar, selain itu teknologi informasi juga memberikan peranan yang besar dalam pengembangan keilmuan dan menjadi sarana utama dalam suatu institusi akademik. Teknologi informasi dan komunikasi dimanfaatkan dalam pembelajaran karena memberikan keuntungan-keuntungan yang tidak dimiliki oleh media pembelajaran lainnya yaitu kemampuan teknologi untuk berinteraksi secara individu terutama di SMA Negeri Colomadu yang merupakan lembaga pendidikan yang dikategorikan memiliki peran yang signifikan dalam memberi skill atau bekal pendidikan untuk siswa dalam penggunaan teknologi informasi untuk digunakan peserta didik dalam mengembangkan materi bukan hanya dari buku saja sehingga dapat meningkatkan prestasi belajar terutama dalam mata pelajaran PPKn. Namun belakangan ini banyak sekali munculnya media didalam jejaring dunia maya yang semakin merebak. Seperti facebook, twitter, google, dan situs yang lainnya dan sedang digemari oleh kalangan remaja pada saat ini. Dengan situs jejaring ini kita bisa mendapatkan informasi apapun dan dapat memperluas komunitas di masyarakat.

Setelah peneliti mengamati di sekolah SMA Negeri Colomadu Karanganyar, kegiatan belajar mengajar di SMA Negeri Colomadu walaupun sarana prasarana sekolah tersebut lengkap. Namun ada beberapa sarana seperti proyektor dan komputer yang rusak atau tidak dapat digunakan, sehingga kegiatan belajar mengajar berbasis TIK masih belum maksimal. Sehingga tidak semua siswa di sekolah dapat menggunakan media pembelajaran dalam kegiatan belajar mengajar di SMA Negeri Colomadu Karanganyar.

\section{. KAJIAN TEORI \\ Pengertian Media Pembelajaran}

Media berasal dari kata "medius" yang artinya tengah, perantara atau pengantar. Media adalah sebuah alat yang mempunyai fungsi penyampaian pesan (bovee, 1997). Dalam bahasa arab media adalah wasail atau 
wasilah yang berarti perantara atau pengantar pesan dari pengirim kepada penerima pesan (arsyad, 2006:3). Pembelajaran adalah sebuah proses komunikasi antara peserta didik, guru dan bahan ajar. Komunikasi tidak akan berjalan lancar tanpa bantuan sarana penyampai pesan atau media. Media yang digunakan dalam pembelajaran disebut media pembelajaran, yang mempunyai fungsi sebagai perantara pesan. Dalam hal ini adalah materi pelajaran kepada peserta didik.

Dalam pembelajaran, media memegang peranan penting dalam mencapai sebuh tujuan belajar. Hubungan komunikasi antara guru dan peserta didik akan lebih baik dan efisien jika menggunakan media. Media dalam proses belajar mengajar memiliki dua peranan penting, yaitu (1) media sebagai alat bantu mengajar atau sering disebut dengan dependent media karena posisi media disini sebagai alat bantu (efektivitas), dan (2) media sebagai sumber belajar yang digunakan sendiri oleh peserta didik secara mandiri atau sering disebut dengan independent media. Independent media dirancang secara sistematis agar danat menyalurkan informasi secara terarah 8 mencapai tujuan pembelajaran yang teıan ditentukan (hamalik, 1984).

Media pembelajaran adalah alat atau bentuk stimulus yang berfungsi untuk menyampaikan pesan pembelajaran. Bentukbentuk stimulus dapat dipergunakan sebagai media diantaranya adalah hubungan atau interaksi manusia, realita, gambar bergerak atau tidak, tulisan, dan suara yang direkam. Kelima bentuk stimulus ini akan membantu peserta didik mempelajari bahas asing. Namun demikian, tidaklah mudah mendapatkan kelima bentuk itu didalam satu waktu atau tempat.

Untuk menarik minat peserta didik program harus mempunyai tampilan yang artistik maka estetika juga merupakan kriteria. Kriteria penilaian yang terakhir adalah fungsi secara keseluruhan. Program yang diberikan harus memberikan pembelajaran yang di inginkan oleh peserta didik. Sehingga pada waktu seseorang selesai menjalankan program dia akan merasa telah belajar sesuatu.

\section{Jenis-Jenis Media Pembelajaran}

Media cukup banyak macam ragamnya, ada media yang hanya dapat dimanfaatkan bila ada alat untuk menampilkannya. Ada pula yang penggunaannya tergantung pada hadirnya seorang guru atau pembimbing (teacher independent). Media yang tidak harus tergantung pada hadirnya guru lazim disebut media instruksional dan bersifat self contained, contohnya penggunaan multimedia interaktif berbasis komputer, dimana materi, tugas dan latihan serta umpan balik yang diperlukan telah diprogramkan secara ter integrasi dalam CBI tersebut.

Dari berbagai ragam dan bentuk dari media pembelajaran, pengelompokan atas media dan sumber belajar dapat juga ditinjau dari jenisnya, yaitu dibedakan menjadi media audio, media visual, media audio-visual, dan media serba neka. Media audioa bisa berupa radio, piringan hitam, pita audio, tape recorder, dan telepon. Media visual bisa berwujud media viual diam : foto, poster, buku, majalah, surat kabar, buku referensi, dan barang hasil cetakan lain, gambar, kliping, film bingkai atau slide, film rangkai atau film strip, transparansi, mikrofis, overhead proyektor, grafik, bagan, diagram, sketsa, gambar kartun, peta, dan globe.

Media objek dan media interaktif berbasis komputer. Media objek merupakan media tiga dimensi yang menyampaikan informasi tidak dalam bentuk penyajian, melainkan melalui ciri fisiknya sendiri, seperti ukurannya, bentuknya, beratnya, susunannya, warnanya, fungsinya, dan sebagainya. Media ini dapat dibagi menjadi dua kelompok, yaitu media objek sebenarnya dan media objek pengganti, sedangkan media interaktif berbasis komputer adalah media yang menuntut peserta didik untuk berinteraksi selain melihat atau mendengarkan. Contoh media interaktif berbasis komputer adalah program interaktif dalam pembelajaran berbasis komputer. Dari kelima bentuk media tersebut media yang terakhir merupakan media dan sumber 
terbaik yang dapat digunakan sebagai sumber media komunikasi. Karakteristik terpenting kelompok media ini adalah bahwa peserta didik tidak hanya memperhatikan media atau objek, melainkan juga dituntut untuk berinteraksi selama mengikuti pelajaran. Sedikitnya ada tiga macam interaksi. Interaksi yang pertama adalah yang menunjukan peserta didik berinteraksi dengan sebuah program, misalnya peserta didik diminta mengisi blanko pada bahan belajar terprogram. Bentuk interaksi kedua adalah peserta didik berinteraksi dengan media komputer, misalnya $\mathrm{CD}$ interaktif, simulator, laboraturium bahasa, laboraturium komputer, atau kombinasi biasanya berbentuk video interaktif. Bentuk interaksi ketiga adalah mengatur interaksi antara peserta didik secara teratur, tetapi tidak terprogram: sebagai contoh dapat dilihat dalam berbagai permainan pendidikan atau simulasi yang melibatkan peserta didik dalam kegiatan atau masalah yang mengharuskan mereka untuk membalas serangan lawan atau kerja sama dengan teman sekelompok dalam memyelesaikan masalah. Dalam hal ini peserta didik harus dapa menyesuaikan diri dengan situasi yang timbul karena tidak ada batasan yang kaku mengenai jawaban yang benar.

\section{Fungsi Media Pembelajaran}

Media mempunyai multimakna, baik dilihat secar terbatas maupun secara luas. Munculnya berbagai macam definisi disebabkan adanya perbedaan dalam sudut pandang, maksud, dan tujuannya. AECT atau association for education and communication technology memaknai media sebagai berbagai bentuk yang dimanfaatkan dalam proses penyaluran informasi. NEA atau national education association memaknai media sebagai segala benda yang dapat dimanipulasi, dilihat, didengar, dibaca, dan dibicarakan beserta instrumen yang digunakan untuk kegiatan tersebut. Beberapa pandangan menurut para ahli tentang media, yaitu Gagne yang menempatkan media sebagai komponen sumber, mendefinisikan media sebagai "komponen sumber belajar di lingkungan peserta didik yang dapat merangsangnya untuk belajar." Briggs berpendapat bahwa media harus didukung sesuatu untuk mengkomunikasikan materi pelajaran supaya terjadi proses belajar, yang mendefinisikan media sebagai wahana fisik yang mengandung materi intruksional. Wilbur Schramm mencermati pemanfaatan media sebagai suatu teknik untuk menyampaikan pesan, dimana ia mendefinisikan media sebagai teknologi pembawa informasi atau pesan pembelajaran. Media secara luas atau makro, adalah segala sesuatu yang dapat merangsang terjadinya proses belajar pada diri peserta didik.

Menurut Sudjana (2002) banyak orang membedakan pengertian antara media dan alat peraga. Namun tidak sedikit yang menggunakan kedua istilah itu secara bergantian untuk menunjuk alat atau benda yang sama atau interchangeable. Perbedaan media dan alat peraga terletak pada fungsinya dan bukan pada substansinya. Suatu sumber belajar disebut alat peraga bila hanya berfungsi sebagai alat bantu pembelajaran saja; dan sumber belajar disebut media apabila merupakan bagian integral dari seluruh proses atau suatu kegiatan pembelajaran dan ada semacam pembagian tanggung jawab antara guru di satu sisi dan sumber lain atau media di sisi lain.

Informasi adalah fakta atau apapun yang dapat digunakan sebagai input dalam menghasilkan informasi. Sedangkan data merupakan bahan mentah, data merupakan input yang setelah diolah berubah bentuknya menjadi output yang disebut informasi. Informasi ialah sejumlah data yang telah diolah melalui pengolahan data dalam rangka menguji tingkat kebenarannya dan ketercapaiannya sesuai dengan kebutuhan. Ada tiga hal yang penting yang harus diperhatikan dari informasi yaitu: (1) informasi merupakan hasil pengolahan data (2) memberikan makna (3) berguna atau bermanfaat.

Ciri-ciri informasi yang berkualitas menurut Mc.leod (1997) ada empat, yaitu (1) 
akurat, artinya informasi mencerminkan kedaan yang sebenarnya. Pengujiannya biasanya dilakukan oleh beberapa orang yang berbeda, dan apabila hasilnya sama, maka data tersebut disebut akurat, (2) tepat waktu, artinya informasi harus tersedia pada saat informasi diperlukan, (3) relevan artinya informasi yang diberikan harus sesuai dengan yang dibutuhkan (4) lengkap, artinya informasi harus diberikan secara utuh tidak setengah-setengah.

\section{Hakikat Teknologi Informasi}

Istilah teknologi informasi mulai populer di akhir dekade 70-an. Pada masa sebelumnya istilah teknologi informasi dikenal dengan teknologi komputer atau pengelolaan data elektronik atau EDP atau elektronik data processing. Menurut kamus oxford (1995), teknologi informasi adalah studi atau penggunaan peralatan elektronika, terutama komputer untuk menyimpan, menganalisis, dan mendistribusikan informasi apa saja, termasuk kata-kata, bilangan, dan gambar. Definisi tersebut lebih dikembangkan oleh martin yang memberikan makna bahwa teknologi informasi tidak hanya terbatas pada teknologi komputer baik perangkat keras maupun perangkat lunak yang digunakan untuk memproses dan menyimpan informasi, melainkan juga mencakup teknologi komikasi untuk mengirimkan informasi.

Dari definisi martin dapat dilihat adanya keterkaitan erat antara teknologi informasi dan komunikasi, teknologi informasi lebih pada sistem pengolahan informasi sedangkan teknologi komunikasi berfungsi untuk pengiriman informasi.

\section{Hakikat Teknologi Komunikasi}

Teknologi komunikasi adalah perangkatperangkat teknologi yang terdiri dari hardware, software proses, dan sistem yang digunakan untuk membantu proses komunikasi yang bertujuan agar komunikasi berhasil atau komunikatif. Teknologi komunikasi lebih menekankanpada perangkat elektronik sebagaimana dikemukakan oleh Everett M. Rogers, bahwa kata kunci dari teknologi komunikasi adalah electronic technology: "electronics technology these theis allous as to build virtually and kind of communication device that one mighatewish at a price".

Menurut rogers, teknology komunikasi adalah peralatan perangkat kera dalam sebah struktur organisasi yang mengandung nilai sosial, yang memungkinkan setiap individu mengumpulkan, mengolah, dan saling bertukar informasi dengan individu lain. Jadi, teknologi komunikasi merupakan wujud hasil ciptaan dan temuan manusian dalam upaya memenuhi kebutuhan untuk berhubungan satu sama lain dengan cepat, jelas dan menjangkau. Seperti contoh Indonesia memiliki satelit komunikasi Palapa tahun 1976. Tercakup dalam definisi tersebut semua perangkat keras, perangkat lunak, kandungan isi, dan infrastruktur komputer maupun komunikasi. Istilah TIK atau ICT ( information and communication technologi) atau yang dikalangan negara Asia berbahasa inggris disebut sebagai infocom, muncul setelah berpadunya teknologi komputer (baik perangkat keras maupun perangkat lunak) dan teknologi komunikasi sebagai sarana penyebaran informasi pada paruh kedua abad ke-20.

Menurut anantta sannai (2004) teknologi informasi dan komunikasi atau TIK adalah sebuah media atau alat bantu dalam memperoleh pengetahuan antara seseorang kepada orang lain.

Sedangkan menurut Kementrian Riset dan Teknologi (2006:6) teknologi informasi dan komunikasi atau TIK sebagai bagian dari ilmu pengetahuan dan teknologi (IPTEK) secara umum adalah semua teknologi yang berhubungan dengan pengambilan, pengumpulan, pengolahan, penyimpanan, penyebaran, dan penyajian informasi. Perpaduan dari kedua teknolgi tersebut berkembang sangat pesat, jauh melampaui bidang-bidang teknologi lainnya. Pada tingkat global, perkembangan TIK telah mempengaruhi seluruh bidang kehidupan umat manusia. Intruksi TIK ke dalam bidang-bidang teknologi lain telah sedemikian jauh, sehingga tiada satu pun 
peralatan hasil inovasi teknologi yang tidak memanfaatkan perangkat TIK.

Prestasi adalah hasil dari suatu kegiatan yang telah dikerjakan, diciptakan baik secara individu maupun secara kelompok. Sedangkan menurut Mas'ud Hasan Abdul Dahar bahwa prestasi adalah apa yang telah dapat diciptakan, hasil pekerjaan, hasil yang menyenangkan hati yang diperoleh dengan jalan keuletan kerja. Dari pengertian yang dikemukakan tersebut di atas, jelas terlihat perbedaan pada kata-kata tertentu sebagai penekanan, namun intinya sama yaitu hasil yang dicapai dari suatu kegiatan. Untuk itu, dapat dipahami bahwa prestasi adalah hasil dari suatu kegiatan yang telah dikerjakan, diciptakan, yang menyenangkan hati, yang diperoleh dengan jalan keuletan kerja, baik secara individual maupun secara kelompok dalam bidang kegiatan tertentu.

Menurut Slameto (1995), bahwa belajar adalah suatu proses usaha yang dilakukan seseorang untuk memperoleh suatu perubahan tingkah laku yang baru secara keseluruhan, sebagai hasil pengalamannya sendiri dalam interaksi dengan lingkungannya. Secara sederhana dari pengertian belajar sebagaimana yang dikemukakan oleh pendapat di atas, dapat diambil suatu pemahaman tentang hakekat dari aktivitas belajar adalah suatu perubahan yang terjadi dalam diri individu. Ditambahkan bahwa prestasi belajar merupakan hasil yang mengakibatkan perubahan dalam diri individu sebagai hasil dari aktivitas dalam belajar. Setelah menelusuri uraian di atas, maka dapat dipahami bahwa prestasi belajar adalah hasil atau taraf kemampuan yang telah dicapai siswa setelah,mengikuti proses belajar mengajar dalam waktu tertentu baik berupa perubahan tingkah laku, keterampilan dan pengetahuan dan kemudian akan diukur dan dinilai yang kemudian diwujudkan dalam angka atau pernyataan, Ade Sanjaya (2011)

\section{Faktor-faktor yang mempengaruhi Prestasi Belajar}

Untuk mencapai prestasi belajar siswa sebagaimana yang diharapkan, maka perlu diperhatikan beberapa faktor yang mempengaruhi prestasi belajar antara lain; faktor yang terdapat dalam diri siswa (faktor intern), dan faktor yang terdiri dari luar siswa (faktor ekstern). Faktor-faktor yang berasal dari dalam diri anak bersifat biologis sedangkan faktor yang berasal dari luar diri anak antara lain adalah faktor keluarga, sekolah, masyarakat dan sebagainya.

\section{Hasil Penelitian yang Relevan}

Penelitian bertujuan untuk melihat Pengaruh Pemanfaatan Pembelajaran Berbasis ICT terhadap Kreativitas Guru dalam Membuat Media Pembelajaran di kelas XI SMA Negeri 1 Seputih Banyak tahun pelajaran 2011-2012. Adapun pengaruh tentang pemanfaatan pembelajaran berbasis Information communication and technology (ICT) atau penggunaan teknologi informasi dan komunikasi apakah sudah digunakan semaksimal mungkin di SMA Negeri 1 Seputih Banyak Lampung Tengah. Metode yang digunakan dalam penelitian ini adalah metode deskriptif kuantitatif dengan teknik angket sebagai teknik pokok, serta teknik penunjang yaitu wawancara dan dokumentasi, sedangkan yang menjadi populasi sampel adalah siswa kelas XI SMA Negeri 1 Seputih Banyak sebanyak 48 orang siswa.

\section{Kerangka Berfikir}

Kerangka Berpikir pemikiran dari peneliti adalah suatu sistem atau alur mengenai hubungan antara variabel satu dengan variabel lainnya dan sudah dijabarkan melalui deskripsi kalimat dan skematis dalam bentuk gambar secara singkat, sederhana dan jelas. Dan dengan berdasar deskripsi teori yang telah diuraikan diatas, selanjutnya diajukan kerangka berpikir dan model hubungan antara masing - masing variabel dalam penelitian ini. Sesuai dengan ruang lingkup penelitian yaitu media pembelajaran berbasis TIK dan prestasi belajar. Keseluruhan faktor tersebut mempunyai kaitan yang sangat erat antar variabel dengan variabel lainnya.

Adapun kerangka berpikir dalam penelitian ini dirumuakan sebagai berikut: 


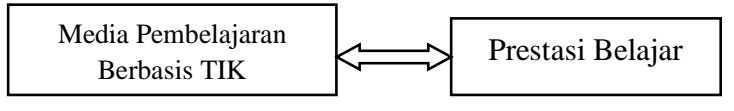

Gambar 1. Skema Kerangka Berpikir

Keterangan

$\mathrm{X}$ : Media Pembelajaran Berbasis TIK

Y : Prestasi Belajar

Media pembelajaran berbasis TIK sangat eraat kaitannya dengan prestasi belajar seorang siswa atau peserta didik, dari kerangka berpikir di atas diharapkan peran media pembelajaran berbasis TIK nantinya akan meningkatkan prestasi belajar pada peserta didik.

\section{METODE PENELITIAN}

Tempat penelitian

Penelitian ini dilaksanakan di SMA N Colomadu Karanganyar pada siswa kelas XI tahun pelajaran 2016/2017

Waktu penelitian

Waktu penelitian dilaksanakan pada bulan Maret sampai juli 2016

Bentuk dan Strategi Penelitian

Penelitian ini dilaksanakan di SMA Negeri Colomadu Kabupaten Karanganyar. Peneliti memilih SMA Negeri Colomadu Kabupaten Karanganyar dengan pertimbangan dan alasan sebagai berikut:

1. Penggunaan media pembelajaran berbasis TIK di sekolah kurang maksimal penggunaannya dalam menunjang pembelajaran.

2. Terdapat masalah didalam pembelajaran khususnya PPKn di kelas XI sehingga peneliti merasa tertarik dan perlu menelitinya.

Berdasarkan sifat dan karakteristik permasalahannya, pendekatan penelitian yang digunakan dalam penelitian ini adalah penelitian tindakan kelas (PTK). Tindakan ini bertujuan untuk mengatasi permasalahan yang berkaitan dengan penggunaan media pembelajaran berbasis TIK terhadap prestasi belajar siswa kelas XI di SMA Negeri Colomadu Kabupaten Karanganyar tahun pelajaran 2016/2017.

Model penelitian tindakan ini adalah kolaboratif antara siswa, peneliti, guru dan kepala sekolah. Kegiatan diawali dengan membandingkan kondisi awal untuk mengidentifikasi permasalahan pada prestasi belajar siswa kelas XI SMA Negeri Clomadu Kabupaten Karangnyar.

\section{Data dan Sumber data}

Jenis yang diperlukan dalam penelitian ini adalah :

1. Data kualitatif yang meliputi daftar hadir, data identitas siswa, silabus dan kurikulum 2013

2. Data kualitatif yang meliputi daftar nilai siswa sebelum dan sesudah dilaksanakan penelitian.

Sumber data yang akan dimanfaatkan dalam penelitian ini adalah:

1. Informasi data yang diperoleh dari narasumber, yaitu guru kelas XI SMA negeri Colomadu.

2. Hasil pengamatan/observasi pelaksanaan pembelajaran PPKn dengan menggunakan media pembelajaran berbasis TIK.

3. Arsip atau dokumen, yaitu foto kegiatan proses belajar mengajar pada siklus I.

\section{Objek dan Subjek Penelitian}

Objek penelitian

Variabel bebas : Media Pembelajaran

Berbasis TIK

Variabel terikat : Prestasi Belajar Siswa

Subjek penelitian

Subjek dari penelitian ini adalah siswa kelas XI di SMA Negeri Colomadu Kabupaten Karanganyar tahun ajaran 2016/2017,

\section{Teknik Pengumpulan Data}

Teknik pengumpulan data merupakan cara yang digunakan untuk mengumpulkan data. Penelitian ini menggunakan teknik pengumpulan data yaitu sebagai berikut:

Metode Wawancara

Interview yang sering disebut juga dengan wawancara atau kuesioner lisan adalah sebuah dialog yang dilakukan oleh pewawancara untuk memperoleh informasi dan terwawancara. (Suharsimi Arikunto 2008:154)

Wawancara dalam penelitian ini digunakan untuk mengetahui, mempelajari kegiatan yang tidak dapat diamati secara 
langsung dan memperoleh gambaran secara luas mengenai pelaksanaan tindakan kelas berhasil atau tidak. Sehingga dalam wawancara ini dapat ditentukan arah yang akan dilanjutkan selanjutnya.

Wawancara dilakukan dengan guru kelas XI untuk memperoleh informasi mengenai kondisi sekolah dan kondisi siswa kelas XI SMA Negeri Colomadu. Hasil wawancara digunakan untuk menggali dan mencari keterangan yang jelas dan pasti mengenai pola dan sebab kesalahan siswa sehingga dapat diberikan tindakan yang tepat dalam permasalahan yang ditemui. Selain itu juga memperoleh data mengenai penggunaan media berbasis TIK dalam memahami pembelajaran PPKn.

Metode tes

Tes adalah serentetan pertanyaan atau latihan serta alat lain yang digunakan untuk mengukur keterampilan, pengetahuan intelegensi, kemampuan atau bakat yang dimiliki oleh individu atau kelompok (suharsimi Arikunto, 2008:29)

Pemberian tes dimaksudkan untuk mengukur seberapa jauh kemampuan memahami materi pelajaran yang dicapai siswa sebelum dan setelah kegiatan pembelajaran. Tes yang digunakan dalam penelitian ini adalah pretest dan post test.

Apabila siswa mampu mengerjakan soal dengan benar berarti menunjukan bahwa siswa memahami materi yang telah diajarkan, dan apabila sebaliknya berarti pemahaman siswa terhadap materi masih rendah.

Dokumentasi

Pendokumentasian dan perekaman dengan kamera foto, dapat memperjelas berbagai deskripsi dalam berbagai situasi dan perilaku subjek yang diteliti. Analisis dokumentasi dilakukan untuk mengetahui profil kemampuan siswa kelas XI SMA Negeri Colomadu dalam memahami materi serta minat siswa terhadap pembelajaran PPKn dengan menggunakan media pembelajaran berbasis TIK.

\section{Keabsahan Data}

Untuk mendapatkan data secara valid, maka penelitian menggunakan triangulasi.
Lexy J.Moleong (2002:178) menyatakan bahwa triangulasi adalah teknik pemeriksaan keabsahan data yang memanfaatkan sesuatu yang lain diluar data itu untuk keperluan pengecekan atau pembanding terhadap data itu. Triangulasi yang digunakan dalam penelitian ini adalah pertama triangulasi sumber dengan membandingkan apa yang dikatakan siswa dan guru. Triangulasi metode yaitu pembuktian dengan observasi mengenai pelaksanaan penerapan media pembelajaran berbasis TIK.

\section{Teknik Analisis Data}

Pada penelitian ini, data dianalisis sejak tindakan pembelajaran dilakukan dan dikembangkan selama proses refleksi sampai proses penyusunan laporan. Untuk kesinambungan dan kedalaman pengajaran data dalam penelitian ini digunakan analisis deskriptif komparatif dan kritis.

Dengan menggunakan analisis deskriptif kritis komparatif, maka peneliti menjabarkan mengenai berbagai kelemahan dan kelebihan media pembelajaran berbasis TIK, apakah metode tersebut efektif atau tidak serta menganalisis kemajuan pemahaman siswa mengenai media pembelajaran dalam mata pelajaran PPKn dari kondisi awal, siklus I dan siklus II.

Dalam melakukan analisis deskriptif kritis komparatif peneliti melakukan analisis dengan membandingkan hasil evaluasi pada kondisi awal, siklus I dan siklus II dilanjutkan dengan analisis kritis yaitu kelemahan yang terjadi untuk selanjutnya dilakukan perbaikan pada siklus berikutnya.

\section{HASIL DAN PEMBAHASAN \\ Kondisi Awal Penelitian}

Hasil observasi awal menunjukan bahwa dalam proses belajar mengajar guru masih menggunakan metode mengajar ceramah sehingga anak hanya sebagai pendengar dan kurang aktif, motivasi siswa dalam mengikuti pembelajaran mata pelajaran ppkn relatif rendah, masih banyak siswa yang tidak memperhatikan guru ketika mengikuti proses belajar mengajar. Kurikulum yang digunakan di SMA Negeri Colomadu 
menggunakan kurikulum 2013, namun penggunaan media pembelajaran dalam proses belajar mengajar kurang dimaksimalkan.

Dengan melihat kenyataan awal dalam penelitian yang ada, maka seorang guru harus bisa memecahkan permasalahan yang terjadi dalam proses pembelajaran, agar tanggung jawab seorang guru dalam meningkatkan pemahaman materi pelajaran PPKn dapat ditingkatkan, agar hasil ulangan siswa dapat memuaskan sehingga tidak ada yang remidi.

Berdasarkan kondisi awal tersebut, ada dua hal pokok yang perlu diatasi ataupun diperbaiki, yaitu kurangnya perhatian siswa saat mengikuti pelajaran dan metode yang digunakan guru saat mengajarkan materi PPKn. Kemudian peneliti mencoba menerapkan penggunaan media pembelajaran berbasis TIK terhadap prestasi belajar pada siswa kelas XI SMA Negeri Colomadu Kabupaten Karanganyar Tahun Ajaran 2016/2017.

\section{Aktivitas Siswa}

Aktifitas siswa dalam proses pembelajaran pada kondisi awal menunjukan bahwa selama kegiatan belajar mengajar anak cenderung pasif, media pembelajaran tidak digunakan dengan maksimal, ketika guru menerangkan kepada siswa, masih banyak siswa yang tidak mendengarkan guru dan bahkan siswa ramai sendiri.

\section{Perencanaan Siklus I}

Siklus pertama ini dilaksanakan pada hari senin tanggal 25 juli 2016 di kelas XI SMA Negeri Colomadu Kabupaten Karanganyar Tahun Ajaran 2016/2017 dengan menerapkan media pembelajaran berbasis TIK dalam kegiatan belajar mengajar. Pada siklus ini materi pelajaran yang dipelajari adalah penegakan hak asasi manusia di Indonesia. Indikator yang harus dicapai adalah mendiskripsikan tentang pengertian pelangaran hak asasi manusia, kasus pelanggaran hak asasi manusia yang ada di Indonesia, dan penanganan hukum bagi pelanggar hak asasi manusia di Indonesia.

Sebelum dilaksanakan penelitian, peneliti bersama guru pamong melakukan diskusi merencanakan siklus I yang meliputi penyusunan lembar RPP, penyusunan tes, dan media pembelajaran berbasis TIK yang akan digunakan pada siklus 1 . Perencanaan kegiatan pada siklus1 adalah sebagai berikut:

a. Selama pembelajaran peneliti bertindak sebgai pelaksana tindakan, dibantu guru pamong yang bertindak sebagai observer.

b. Penyusunan RPP dengan standart kompetensi penegakan ham di indonesia dengan menggunakan media pembelajaran berbasis TIK.

c. Siswa akan membuat kelompok diskusi untuk mengetahui pemahaman tentang materi penegakan hak asas manusia di Indonesia

d. Menyusun tes untuk mengukur kemampuan siswa setelah diberikan tindakan.

\section{Pelaksanaan Tindakan Siklus I}

Proses pelaksanaan tindakan siklus pertama ini adalah melaksanakan apa yang telah direncanakan pada tahap perencanaan yang telah disusun oleh peneliti. Pelaksanaan pada siklus 1 yang dilakukan oleh peneliti dapat digambarkan sebagai berikut:

\section{Kegiatan Awal}

Sebelum masuk pada kegiatan inti pembelajaran, guru terlebih dahulu memberikan salam, setelah itu dilanjutkan dengan membuat kesepakatan atau kontrak kelas. Guru juga mengkondisikan siswa kedalam situasi belajar yang kondusif dengan merapihkan tempat duduk dan memperlihatkan buku pendamping dan media pembelajaran yang akan digunakan, kemudian menjelaskan tujuan yang ingin dicapai dalam hal ini yaitu tentang penegakan hak asasi manusia di Indonesia. Setelah itu guru mengadakan apersepsi melalui tanya jawab yang dihubungkan dengan materi yang akan dipelajari.

\section{Kegiatan Inti}

Setelah guru membuat kesepakatan dengan siswa, selanjutnya dilanjutkan ke kegiatan inti. Guru menjelaskan materi tentang penegakan hak asasi manusia di 
Indonesia dengan menggunakan media pembelajaran berbasis TIK, yaitu :

\section{Mengamati}

Membaca berbagai kasus pelanggaran hak asasi manusia di Indonesia dari buku pendamping dan powerpoint kemudian menyaksikan penayangan gambar dan video contoh pelanggaran hak asasi manusia.

2. Menanya

Menanyakan sebab-sebab kasus pelanggaran HAM di Indonesia, Menanyakan intisari dari tayangan gambar dan video pelanggaran hak asasi manusia.

3. Mengeksperimenkan/mengeksplorasikan Menentukan sumber data akurat yang ada di lingkungannya terkait dengan kasus pelanggaran HAM di Indonesia, Mengumpulkan data dari berbagai sumber tentang kasus pelanggaran HAM di Indonesia, Mengumpulkan data dari berbagai sumber dengan menggunakan media pembelajaran berbasis TIK tentang sebab-sebab terjadinya kasus pelanggaran HAM di Indonesia

4. Mengasosiasikan

Mencari hubungan pelanggaran HAM dengan aspek sosial budaya dalam kehidupan masyarakat Indonesia, Mencari hubungan pelanggaran HAM dengan nilai-nilai Pancasila.

5. Mengkomunikasikan

Setelah membagi siswa menjadi 6 kelompok yaitu satu kelompok beranggotakan 4 sampai 5 siswa kemudian siswa mempresentasikan hasil analisis tentang berbagai kasus pelanggaran hak asasi mausia di Indonesia, Menyampaikan hasil temuan tentang kasus pelanggaran HAM dalam bentuk lisan, tulisan, gambar atau media lainnya.

\section{Kegiatan Akhir}

Dalam kegiatan akhir guru dan peserta didik bersama-sama menyimpulkan materi tentang penegakan hak asasi manusia di Indonesia yang sudah dipelajari. Guru melakukan post test I berupa 2 soal untuk satu kelompok yang sudah dikerjakan sesudah pembelajaran selasai.

\section{Observasi Siklus I}

Selama tahap pelaksanaan peneliti melakukan observasi sesuai dengan format yang direncanakan selama diskusi berlangsung dengan menggunakan lembar observasi yang telah disiapkan. Tahap observasi atau pengamatan dilaksanakan bersamaan dengan pelaksanaan tindakan.

Pengamatan dilakukan selama proses pembelajaran dengan menggunakan media pembelajaran berbasis TIK melalui penilaian kegiatan siswa secara individu dan kelompok dengan pemberian soal test (instrument penilaian).

\section{Refleksi Siklus I}

Dari pengamatan (observasi) diperoleh data yang akan dianalisis meliputi aktivitas siswa dan hasil belajar PPKn dengan menggunakan media pemelajaran berbasis TIK.

Data-data yang diperoleh observer memberikan gambaran bahwa hasil belajar siswa dalam melaksanakan pembelajaran dengan menggunakan media pembelajaran berbasis TIK masih perlu ditingkatkan pada seluruh tahapan pembelajaran, meskipun telah menunjukan hasil belajar jika dibandingkan dengan awal pelaksanaan penelitian.

Pada saat diskusi sebagian siswa masih terlihat kurang serius, mengobrol dan kurang memperhatikan jalannya diskusi dengan baik. Motivasi belajar dan minat siswa dalam melaksanakan proses pembelajaran masih kurang efektif.

Hasil-hasil yang diperoleh dan permasalahan yang muncul pada pelaksanaan tindakan dipakai sebagai dasar untuk melakukan perncanaan ulng pada siklus berikutnya dengan mencari kekuatan dan kelemahan yang terjadi pada siklus I agar diketahui hal-hal apa saja yang perlu diperbaiki pada siklus I untuk diterapkan pada siklus II.

\section{Hasil dan pembahasan siklus II}

Sebelum dilaksanakan penelitian, selama proses pembelajaran peneliti bertindak 
sebagai pelaksana tindakan dan dibantu oleh guru mitra yang bertindak sebagai observer.

Adapun hasil kegiatan siklus II, yaitu penyusuna RPP, penyusunan lembar observasi, penyusunan tes, dan media yag akan digunakan pada siklus II. Peneliti serta guru mitra, melakukan diskusi membuat perencanaan berdasarkan latar belakang peneliti temukan, yaitu ada banyak siswa yang hasil belajarnya masih dibawah kriteria ketuntasan minimal. Sehingga peneliti dan guru mitra bersepakat bahwa perencanaan siklus II sebagai berikut :

a) Selama pembelajaran peneliti bertindak sebgai pelaksana tindakan, dibantu guru pamong yang bertindak sebagai observer.

b) Penyusunan RPP dengan standart kompetensi penegakan ham di indonesia dengan menggunakan media pembelajaran berbasis TIK.

c) Siswa akan membuat kelompok diskusi untuk mengetahui pemahaman tentang materi penegakan hak asas manusia di Indonesia

d) Menyusun tes untuk mengukur kemampuan siswa setelah diberikan tindakan.

\section{Pelaksanaan Tindakan Siklus II}

Proses pelaksanaan tindakan siklus pertama ini adalah melaksanakan apa yang telah direncanakan pada tahap perencanaan yang telah disusun oleh peneliti. Pelaksanaan pada siklus 1I yang dilakukan oleh peneliti dapat digambarkan sebagai berikut:

\section{Kegiatan Awal}

Sebelum masuk pada kegiatan inti pembelajaran, guru terlebih dahulu memberikan salam, setelah itu dilanjutkan dengan membuat kesepakatan atau kontrak kelas. Guru juga mengkondisikan siswa kedalam situasi belajar yang kondusif dengan merapihkan tempat duduk dan memperlihatkan buku pendamping dan media pembelajaran yang akan digunakan, kemudian menjelaskan tujuan yang ingin dicapai dalam hal ini yaitu tentang penegakan hak asasi manusia di Indonesia. Setelah itu guru mengadakan apersepsi melalui tanya jawab yang dihubungkan dengan materi yang akan dipelajari.

\section{Kegiatan Inti}

Setelah guru membuat kesepakatan dengan siswa, selanjutnya dilanjutkan ke kegiatan inti. Guru menjelaskan materi tentang penegakan hak asasi manusia di Indonesia dengan menggunakan media pembelajaran berbasis TIK, yaitu :

1. Mengamati

Membaca berbagai kasus pelanggaran hak asasi manusia di Indonesia dari buku pendamping dan powerpoint kemudian menyaksikan penayangan gambar dan video contoh pelanggaran hak asasi manusia.

2. Menanya

Menanyakan sebab-sebab kasus pelanggaran HAM di Indonesia, Menanyakan intisari dari tayangan gambar dan video pelanggaran hak asasi manusia.

3. Mengeksperimenkan/mengeksplorasikan Menentukan sumber data akurat yang ada di lingkungannya terkait dengan kasus pelanggaran HAM di Indonesia, Mengumpulkan data dari berbagai sumber tentang kasus pelanggaran HAM di Indonesia, Mengumpulkan data dari berbagai sumber dengan menggunakan media pembelajaran berbasis TIK tentang sebab-sebab terjadinya kasus pelanggaran HAM di Indonesia

\section{Mengasosiasikan}

Mencari hubungan pelanggaran HAM dengan aspek sosial budaya dalam kehidupan masyarakat Indonesia, Mencari hubungan pelanggaran HAM dengan nilai-nilai Pancasila.

5. Mengkomunikasikan

Setelah membagi siswa menjadi 6 kelompok yaitu satu kelompok beranggotakan 4 sampai 5 siswa kemudian siswa mempresentasikan hasil analisis tentang berbagai kasus pelanggaran hak asasi mausia di Indonesia, Menyampaikan hasil temuan tentang kasus pelanggaran HAM dalam bentuk lisan, tulisan, gambar atau media lainnya. 


\section{Kegiatan Akhir}

Dalam kegiatan akhir guru dan peserta didik bersama-sama menyimpulkan materi tentang penegakan hak asasi manusia di Indonesia yang sudah dipelajari. Guru melakukan post test I berupa 10 soal pilihan ganda yang sudah dikerjakan sesudah pembelajaran selasai.

\section{Observasi Siklus II}

Selama tahap pelaksanaan peneliti melakukan observasi sesuai dengan format yang direncanakan selama diskusi berlangsung dengan menggunakan lembar observasi yang telah disiapkan. Tahap observasi atau pengamatan dilaksanakan bersamaan dengan pelaksanaan tindakan.

Pengamatan dilakukan selama proses pembelajaran dengan menggunakan media pembelajaran berbasis TIK melalui penilaian kegiatan siswa secara individu dan kelompok dengan pemberian soal test (instrument penilaian).

\section{Refleksi Siklus II}

Dari pengamatan (observasi) diperoleh data yang akan dianalisis meliputi Aktivitas siswa dan hasil belajar ppkn materi penegakan hak asasi manusia di Indonesia dengan menggunakan media pembelajaran berbasis TIK.

Data-data yang diperoleh observer memberikan gambaran bahwa hasil kegiatan belajar siswa dalam menggunakan media pembelajaran berbasis TIK sangat disukai oleh siswa karena dengan menampilkan gambar dan video tentang hak asasi manusia melalui LCD proyektor, siswa tertarik menyaksikan sehingga siswa dapat memahami penagakan hak asasi manusia di Indonesia secara lebih nyata. maka dengan adanya media pembelajaran berbasis TIK di kelas maka siswa akan mendengarkan pelajaran pada saat guru menyampaikan materi.

Pada saat diskusi siswa lebih aktif dalam membahas materi karena masih mengingat gambar dan tayangan yang disajikan melalui media belajar berbasis TIK, sehingga jalannya diskusi berjalan dengan baik. Motivasi belajar, minat dan perhatian siswa dalam melaksanakan proses pembelajaran dengan menggunakan media pembelajaran berbasis TIK sangat baik.

Hasil-hasil yang diperoleh melalui penggunaan media pembelajaran berbasis TIK pada tindakan siklus II dinilai peneliti cukup memuaskan, sehingga melalui tindakan siklus I peneliti sudah cukup melakukan observasi pada siswa kelas XI SMA Negeri Colomadu Kabupaten Karanganyar Tahun 2016.

\section{Pembahasan Hasil Penelitian}

Dalam pembahasan hasil penelitian ini akan dikemukakan tentang kondisi awal pembelajaran ppkn sampai pelaksanaan tindakan siklus I, yang ditunjukan sebagai berikut:

\section{Kondisi Awal}

Partisipasi Siswa Dalam Pembelajaran Partisipasi siswa selama berlangsungnya kegiatan belajar mengajar dinilai masih "kurang". Diketahui bahwa tidak semua siswa memperhatikan saat guru sedang menjelaskan materi pelajaran. Siswa tidak berani menjawab pertanyaan yang diberikan oleh guru kepada siswa, tidak berani mengungkapkan pendapatnya dengan alasan ragu-ragu terhadap jawabannya sendiri.

Kemudian mengenai hasil belajar siswa yang masih dibawah batas minimal atau dikatakan sangat rendah. Oleh sebab itu halhal yang menjadi catatan kemudian didiskusikan bersama observer untuk menentukan tindakan selanjutnya dalam tahap tindakan siklus yang akan dilaksanakan.

\section{Hasil Belajar Siswa}

Hasil prestasi belajar siswa kelas XI SMA nageri colomadu karanganyar tahun pelajaran 2016, pada kondisi awal dapat dilihat pada tabel berikut ini:

Berdasarkan hasil tes kondisi awal diatas menunjukan bahwa nilai pemahamaan materi PPKn menunjukan bahwa tidak ada siswa yang memperoleh nilai diatas KKM (lebih dari 70) atau 0\% dari 33siswa, dengan ratarata nilai sebesar 63.03. Hal ini dapat dikatakan bahwa selama ini pembelajaran 
PPKn belum dapat dicapai secara maksimal oleh siswa.

Untuk lebih jelasnya dapat dilihat pada grafik dibawah ini:

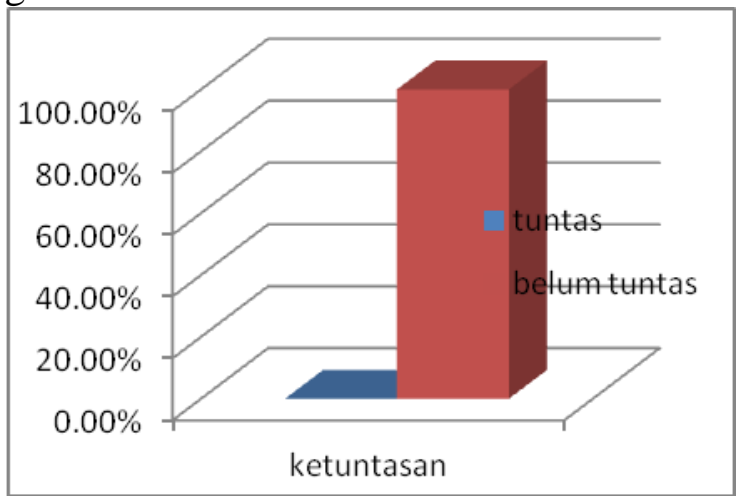

Gambar 4.1 Grafik Ketuntasan Hasil Belajar Kondisi Awal

Dari grafik tersebut bahwa semua siswa $(100 \%)$ belum mencapai ketuntasan belajar, sehingga diperlukan suatu penerapan metode pembelajaran yang tepat untuk meningkatkan prestasi belajar siswa pada mata pelajaran pkn.

\section{Siklus I}

Partisipasi Siswa Dalam Pembelajaran Partisipasi siswa selama berlangsungnya kegiatan belajar mengajar dinilai masih "kurang". Diketahui bahwa tidak semua siswa memperhatikan saat guru sedang menjelaskan materi pelajaran. Siswa tidak berani menjawab pertanyaan yang diberikan oleh guru kepada siswa, tidak berani mengungkapkan pendapatnya dengan alasan ragu-ragu terhadap jawabannya sendiri.

Kemudian mengenai hasil belajar siswa yang masih dibawah batas minimal atau dikatakan sangat rendah. Oleh sebab itu halhal yang menjadi catatan kemudian didiskusikan bersama observer untuk menentukan tindakan selanjutnya dalam tahap tindakan siklus yang akan dilaksanakan.

Hasil Belajar Siswa

Berdasarkan hasil tes kondisi awal diatas menunjukan bahwa nilai pemahamaan materi ppkn siswa memperoleh nilai diatas KKM (lebih dari 70) sebanyak 7 siswa atau 21,21\% dari 33siswa, dengan rata-rata nilai sebesar 56,06 . Hal ini dapat dikatakan bahwa selama ini pembelajaran pkn belum dapat dicapai secara maksimal oleh siswa.
Untuk lebih jelasnya dapat dilihat pada grafik dibawah ini:

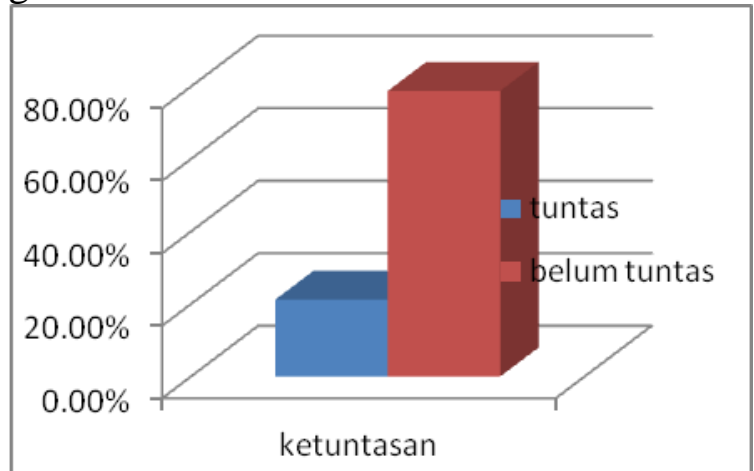

Gambar 4.1 Grafik Ketuntasan Hasil Belajar siklus I

Dari grafik tersebut bahwa sebagian besar siswa $(78,79 \%)$ belum mencapai ketuntasan belajar, sehingga diperlukan suatu penerapan metode pembelajaran yang tepat untuk meningkatkan prestasi belajar siswa pada mata pelajaran pkn.

\section{Siklus II}

Partisipasi Siswa Dalam Pembelajaran

Partisipasi siswa selama berlangsungnya kegiatan belajar mengajar pada siklus II dinilai "baik". Diketahui bahwa siswa sudah berani menjawab pertanyaan yang diberikan oleh guru kepada siswa.

\section{Hasil Prestasi Belajar}

Hasil prestasi belajar siswa kelas XI SMA Negeri Colomadu Karanganyar Tahun Ajaran 2016/2017. Pada siklus II dapat dilihat pada tabel berikut ini:

Berdasarkan hasil tes siklus I diatas menunjukan bahwa nilai pemahamaan materi ppkn siswa memperoleh nilai diatas KKM (lebih dari 70) sebanyak 32 siswa atau 100\% dari 32siswa, dengan rata-rata nilai sebesar 83,12 . Hal ini dapat dikatakan bahwa selama ini pembelajaran PPKn dapat dicapai secara maksimal oleh siswa.

Untuk lebih jelasnya dapat dilihat pada grafik dibawah ini: 


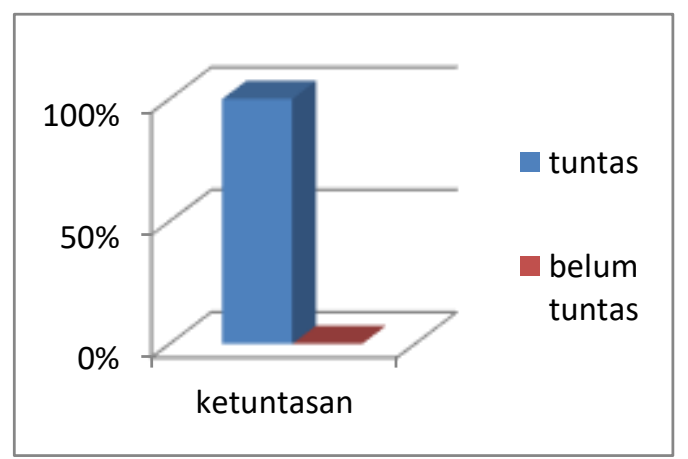

Gambar 4.2 Grafik Ketuntasan Hasil Belajar Siklus 1

Dari grafik tersebut bahwa semua siswa (100\%) dapat mencapai ketuntasan belajar, oleh karena itu penerapan media pembelajaran berbasis TIK dapat meningkatkan prestasi belajar siswa pada mata pelajaran PPKn.

\section{Hasil Dan Pembahasan Siklus}

Berdasarkan hasil evaluasi pembelajaran PPKn materi tentang penegakan hak asasi manusia di Indonesia pada kelas XI SMA Negeri Colomadu karanganyar tahun 2016 sebelum dan sesudah pelaksanaan pembelajaran dengan menggunakan media pembelajaran berbasis TIK dapat dilihat sebagai berikut:

\section{Tabel 4}

Hasil Tes Kondisi Awal, siklus I, dan Siklus II Peningkatan Pemahaman Penegakan Hak Asasi Manusia Melalui Pemanfaatan Media Pembelajaran Berbasis TIK Pada Siswa Kelas XI SMA Negeri Colomadu Kabupaten Karanganyar Tahun 2016/2017

\begin{tabular}{|c|l|l|l|l|l|l|l|}
\hline $\begin{array}{l}\text { N } \\
\text { O }\end{array}$ & $\begin{array}{l}\text { Ketuntas } \\
\text { an }\end{array}$ & \multicolumn{2}{|l|}{$\begin{array}{l}\text { Kondisi } \\
\text { awal }\end{array}$} & \multicolumn{2}{l|}{ Siklus 1 } & \multicolumn{2}{l|}{ Siklus II } \\
\cline { 3 - 8 } & $\begin{array}{l}\text { Jumla } \\
\text { h }\end{array}$ & $\begin{array}{l}\text { Juml } \\
\text { ah }\end{array}$ & $\begin{array}{l}\text { jum } \\
\text { lah }\end{array}$ & $\%$ \\
\hline 1 & Tuntas & - & - & 7 & $\begin{array}{l}21, \\
21\end{array}$ & 32 & $\begin{array}{l}10 \\
0\end{array}$ \\
\hline 2 & $\begin{array}{l}\text { Belum } \\
\text { tuntas }\end{array}$ & 33 & 1 & 26 & $\begin{array}{l}78, \\
79\end{array}$ & - & - \\
\hline & Jumlah & 33 & 1 & 33 & 100 & 32 & $\begin{array}{l}10 \\
0\end{array}$ \\
& & 0 & & & & 0 \\
\hline \multicolumn{2}{|l|}{ Rata-rata } & 63,03 & & 56,06 & & 83,12 \\
\hline
\end{tabular}

Pada tabel III dapat diketahui bahwa prestasi belajar PPKn materi penegakan hak asasi manusia di Indonesia pada siswa kelas XI SMA Negeri Colomadu Karanganyar tahun ajaran 2016 pada kondisi awal menunjukan bahwa dari 33 siswa, yang dinyatakan tidak tuntas atau mempunyai nilai dibawah 70 sebanyak 33 siawa $(100 \%)$ dengan rata-rata 63,03. Pada siklus I siswa yang tuntas sebanyak 7 siswa $(21,21 \%)$ sedangkan siswa yang belum tuntas dinyatakan 26 siswa $(78,79 \%)$ dengan ratarata 56,06. Pada siklus II siswa tuntas sebanyak 32 siswa (100\%) dengan rata-rata 83,12 .

Untuk lebih jelasnya, berikut peneliti gambarkan bentuk grafik mengenai peningkatan prestasi belajar pkn dengan pokok bahasan penegakan hak asai manusia di indonesia pada kelas XI SMA Negeri Colomadu Karanganyar tahun 2015/2016 dari kondisi awal sampai siklus I sebagai berikut:

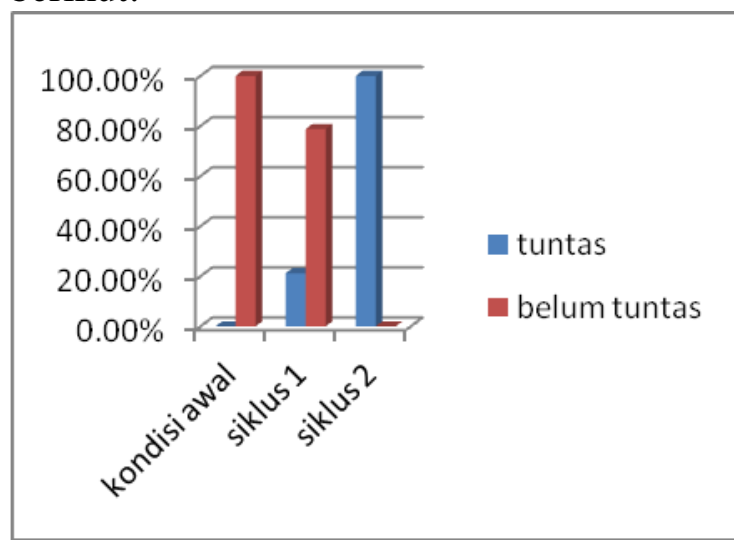

Gambar 4.3 Grafik Perbandingan Hasil Belajar PPKn Pada Kondisi Awal dan Siklus 1

Berdasarkan hasil evaluasi pembelajaran tersebut, peneliti menyimpulkan bahwa pembelajaran dengan menggunakan media pembelajaran berbasis TIK dapat meningkatkan prestasi belajar PPKn pada pokok bahasan penegakan hak asasi manusia di Indonesia pada siswa kelas XI SMA Negeri Colomadu Karanganyar.

E. KESIMPULAN DAN SARAN

\section{Kesimpulan}

Berdasarkan penelitian dan pembahasan maka diperoleh kesimpulan bahwa penggunaan media pembelajaran berbasis TIK dapat meningkatkan pemahaman materi tentang penegakan hak asasi manusia di Indonesia siswa kelas XI SMA Negeri Colomadu Karanganyar tahun ajaran 2016, 
pada kondisi awal menunjukan bahwa dari 33 siswa, yang dinyatakan tidak tuntas atau mempunyai nilai dibawah 70 yaitu sebanyak 33 siswa $(100 \%)$ dengan rata-rata nilai 63,03. Pada siklus I siswa yang dinyatakan tuntas atau mempunyai nilai diatas 70 sebanyak 7 siswa $(21,21 \%)$ sedangkan siswa yang belum tuntas dinyatakan 26 siswa $(78,79 \%)$ dengan rata-rata 56,06. Pada siklus II siswa tuntas sebanyak 32 siswa (100\%) dengan rata-rata 83,12. Dengan demikian dapat peneliti menyimpulkan bahwa penggunaan media pembelajaran berbasis TIK dapat meningkatkan pemahaman materi tentang penegakan hak asasi manusia di Indonesia pada siswa kelas XI SMA Negeri Colomadu Karanganyar tahun ajaran 2016/2017.

\section{Saran-Saran}

Dari kesimpulan diatas, beberapa hal yang sebaiknya dilakukan guru dalam meningkatkan pembelajaran khususnya meningkatkan prestasi belajar siswa, peneliti menyarankan beberapa hal antara lain:
Kepada guru

Hendaknya guru dalam mengajar perlu menggunakan metode pembelajaran yang bervariasi, sehingga siswa merasa senang dan tertarik dalam mengikuti kegiatan pembelajaran yang menggunakan media pembelajaran berbasis TIK, sehingga siswa merasa tertarik untuk mengikuti kegiatan pembelajaran.

Kepada siswa

Kepada siswa selalu menumbuhkan motivasi yang tinggi dalam mengikuti setiap mata pelajaran yang diberikan oleh guru, hal tersebut diharapkan dapat meningkatkan prestasi belajar siswa.

Pihak sekolah

Pihak sekolah sebaiknya segera menyediakan sarana dan prasarana yang dapat menunjang kegiatan belajar mengajar sehingga dapat berhasil sesuai dengan tujuan yang diharapkan agar tidak mengalami banyak kendala dalam kegiatan belajar mengajar.

\section{DAFTAR PUSTAKA}

Azhar arsyad, 2009. Media pembelajaran. Jakarta: Rajawali Pers

Amir hamsyah suleiman, 1988. Media audio-visual untuk pengajaran, penerangan dan penyuluh. Jakarta: Gramedia

Ade Sanjaya, 2011. Pretasi Belajar. Bandung

Abu Muhammad Ibnu Abdullah, 2008. Prestasi Belajar

Djamarah, Syaiful Bachri. 2002. Strategi belajar mengajar. Jakarta: Rineka Cipta.

Oemar Hamalik, 1989. Media pendidikan. Bandung:citra aditya bakti

Hamzah B.Uno, Nina Lamatenggo. 2011. Teknologi Komunikasi Dan Informasi Pembelajaran. Jakarta:Bumi Aksara

Rohan, Ahmad,1997.Media Instructional Educatif, Rineka Cipta, Jakarta.

Rusman, Deni Kurniawan, Cepi Riyana. 2013. Pembelajaran Berbasis Teknologi Informasi

Dan Komunikasi: Mengembangkan Profesionalitas Guru. Jakarta: Rajawali Pers.

Saifuddin Azwar, 1996. Tes prestasi: fungsi pengembangan pengukuran prestasi belajar.

Yogyakarta. Pustaka Belajar

Soekartawi, 2005, manfaat E-Learning Dalam Pengajaran, Erlangga, Jakarta.

Sudjana dan Riva'i, 1989. Media Pengajaran,Sinar baru, Bandung.

Sugiyono, 2013. Metode penelitian pendidikan, bandung:Alfabeta

Suharsimi Arikunto, 2010. Prosedur penelitian, jakarta: PT Rineka Citra

Sugiyono, 2012. Metode penelitian kuantitatif kualitatif dan R\&D, Bandung:Alfabeta. 